\title{
Interference competition for space in nursery habitats: density-dependent effects on growth and dispersal in juvenile shore crabs Carcinus maenas
}

\author{
Per-Olav Moksnes* \\ Department of Marine Ecology, Göteborg University, Kristineberg Marine Research Station, 45034 Fiskebäckskil, Sweden
}

Present address: Department of Marine Ecology, Göteborg University, Box 461, 40530 Göteborg, Sweden

\begin{abstract}
In marine organisms with dispersing larval stages, current ecological theory suggests that recruitment of benthic juveniles may be limited by juvenile habitats and regulated by early postsettlement processes. However, few studies have attempted to identify the density-dependent mechanisms responsible for these demographic bottlenecks. I conducted a series of experiments to assess if interference competition for space, within nursery habitats, could result in density-dependent juvenile growth and dispersal from refuge habitats, and regulate local populations of juvenile shore crabs Carcinus maenas in shallow nursery areas in Sweden. In laboratory mesocosms, increased natural densities of similarly sized crabs resulted in decreased growth and increased per capita emigration from mussel habitats, even though food was provided in excess, suggesting that competition for space and mutual interference mediated the density-dependent growth and dispersal. This was supported in a field experiment where a density-dependent relation was found between the abundance of juvenile crabs in nursery areas and their migration rates to experimental mussel patches. The results suggest that interference competition for space and density-dependent emigration from refuge habitats, coupled with habitat-specific mortality, is an important regulating mechanism for juvenile shore crab populations, in particular for older juvenile cohorts that have escaped inter-cohort cannibalism through a size refuge. Density-dependent effects on growth were found only at unusually high natural densities and may, therefore, be less important as a regulating mechanism. However, negative effects on feeding rates and growth at high conspecific densities may represent an important selective force in juvenile migration behavior. Density-dependent dispersal was found at juvenile densities that are regularly found in nursery areas, suggesting that nursery habitats become saturated with juveniles during the recruitment season and represent a limiting resource for local populations, consistent with field observations of shore crab populations in the study area.
\end{abstract}

KEY WORDS: Carcinus maenas $\cdot$ European green crab $\cdot$ Recruitment regulation · Density-dependence · Interference competition · Migration · Growth · Nursery habitat

\section{INTRODUCTION}

In benthic marine organisms with pelagic larvae, early post-settlement processes may play a significant role in population regulation and community organization (review by Ólafsson et al. 1994, Caley et al. 1996, Hunt \& Scheibling 1997). Predation is a dominant source of mortality for early recruits, and young juveniles of most mobile species are concentrated in structurally complex microhabitats that provide refuge from predators (see Gosselin \& Qian 1997, Hunt \& Scheibling 1997 for review). These nursery habitats are thought to play an important role in the survival of young juveniles and may become limiting for local recruitment when larval supply is high (Steger 1987, Wahle \& Steneck 1991, Beck 1997, Butler \& Herrnkind 1997). However, the density-dependent mechanisms creating these shelter bottlenecks are not well understood.

Interference competition for space in nursery habitats represents a potential regulatory mechanism which, 
until recently, has been little studied in mobile epibenthic organisms. In species whose larval settlement is concentrated to a limited period of the year, the combined effects of habitat selection by larvae and juveniles, and increased survival in nursery habitats may result in very high densities of juveniles within a restricted area, and result in interference or exploitation competition for space or food. These processes would act as regulating mechanisms of local populations if they result in density-dependent growth, emigration or mortality of the recruits. Space competition, mediated through agonistic interactions between juveniles, can create mutual interference that negatively affects feeding rates and subsequent growth. Since early juvenile mortality of many benthic species is strongly size-specific (see Gosselin \& Qian 1997, Hunt \& Scheibling 1997 for review), density-dependent growth and duration of juvenile stages vulnerable to predation could constitute an important regulatory mechanism in these species (Fogarty et al. 1991). Similarly, interference competition for space may also increase juvenile mobility and cause density-dependent emigration from refuge habitats. This could regulate a local population if juveniles disperse out of the population or if the emigration is coupled with habitat specific mortality. Although habitat specific mortality of young juveniles appears to be very common in marine benthic organisms (see Hunt \& Scheibling 1997 for review), density-dependent juvenile dispersal has received little attention as a regulating mechanism (but see Iribarne et al. 1994). The distribution of young juveniles in motile species is generally assumed to be static within nursery habitats (Bell \& Westoby 1986) and juvenile migration is often ignored in studies assessing recruitment in epibenthic organisms although early post-settlement dispersal is common and can be an important process for local population dynamics (see Palmer et al. 1996 for review).

The shore crab Carcinus maenas L. is an epibenthic omnivore widely distributed on both hard and soft intertidal and shallow subtidal substrata. It is native to Europe, but it is also found in the northwestern Atlantic, and has recently been invading the northeast Pacific, South Australia and South Africa (see Yamada 2001 for review). In western Sweden, the megalopae (postlarvae) settle predominantly from July to September (Moksnes 1999) and juveniles (0- and 1-group; 1 to $20 \mathrm{~mm}$ spine-to-spine carapace width, CW) are found mainly in shallow (<1 m), soft sediment bays (Pihl 1986). Both megalopae and young juvenile crabs actively select structurally complex habitats for shelter (Hedvall et al. 1998, Moksnes 2002, Moksnes et al. 2003), and juveniles are concentrated at high densities (up to

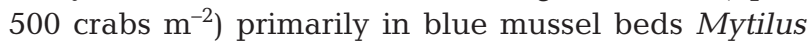
edulis L. but also in eelgrass beds Zostera marina L. and macroalgae (Moksnes 2002). Juveniles inhabit these shallow nursery areas until they attain maturity during their second summer when they disperse to deeper habitats (Eriksson \& Edlund 1977, Pihl \& Rosenberg 1982).

Predation mortality in young juvenile shore crabs is both size- and habitat-specific, indicating that local populations could be regulated by density-dependent growth and dispersal from nursery habitats, respectively. Predation mortality on young juveniles can be very high (10 to $50 \%$ mortality d $\mathrm{d}^{-1}$; Moksnes 2002) and 2 to 6 times higher on open sand compared to structurally complex habitats (Moksnes et al. 1998), suggesting that nursery habitats play a key role in the survival of new recruits. Predation rates are also strongly size-specific and dropped from $50 \%$ mortality $\mathrm{d}^{-1}$ on 1st instar crabs (1.5 mm CW) tethered in seagrass beds to under $10 \%$ on crabs larger than $5 \mathrm{~mm} \mathrm{CW}$, due to a size refuge from juvenile cannibalism (Moksnes et al. 1998). Recent studies have demonstrated densitydependent aggression and cannibalism between juvenile crabs in mussel beds, and that mutual interference decreases per capita consumption rates when crab densities are high (Moksnes 2004). However, available data on density-dependent effects of juvenile shore crab growth are inconclusive (Adelung 1971, KleinBreteler 1975a,b) and it is not known whether these density-dependent interactions have a significant effect on growth or dispersal of juvenile crabs.

The goal of this study was to assess whether interference competition for space within nursery habitats could result in density-dependent juvenile growth and dispersal from refuge habitats, and regulate local populations of juvenile shore crabs in shallow nursery areas in Sweden.

\section{MATERIALS AND METHODS}

Expt 1: density-dependent growth. To assess whether interference competition for space between juvenile shore crabs could negatively affect growth, a 30 d laboratory experiment was performed in August 1998 at Kristineberg Marine Research Station on the Swedish west coast $\left(58^{\circ} 15^{\prime} \mathrm{N}, 11^{\circ} 27^{\prime} \mathrm{E}\right)$. The experiment was performed in 12 cylindrical flow-through (3 $1 \mathrm{~min}^{-1}$ ) mesocosm tanks $\left(0.19 \mathrm{~m}^{2} ; 80 \mathrm{l}\right)$ provided with $3 \mathrm{~cm}$ depth of sieved $(<750 \mu \mathrm{m})$ dry beach sand and filtered $(<750 \mu \mathrm{m})$ surface water. The water was pumped in from $1 \mathrm{~m}$ depth in a shallow bay next to the laboratory and therefore, showed natural fluctuation in temperature and salinity found in shallow nursery areas. A $750 \mu \mathrm{m}$ filter on the in-flowing water prevented introduction of crab larvae and predators, but allowed smaller food particles and prey (mainly gastropods and 
bivalves) to enter the tanks. Two sources of light were used in the laboratory giving $16 \mathrm{~h}$ light: $6 \mathrm{~h}$ dark and $1 \mathrm{~h}$ of diffuse light at dusk and dawn in all experiments, approximating natural fall light conditions in Sweden. Each tank was provided with sand and 20 blue mussel shell halves ( 70 to $80 \mathrm{~mm}$ long) placed in the center of the tank in a small patch, covering approximately $25 \%$ of the surface area. Three densities of 1st juvenile instar (J1) crabs were assessed (10, 40 and 160 crabs per tank, equivalent to 53, 210 and 842 crabs $\mathrm{m}^{-2}$, respectively), which were randomly allocated to 12 tanks $(n=4)$. The tested densities represent natural settlement densities, which can reach up to

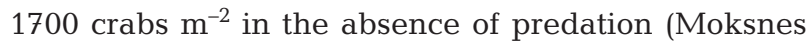
2002). First instar shore crabs used in the experiments were collected as megalopae from the surface plankton using artificial settlement collectors (see Moksnes \& Wennhage 2001 for details regarding the sampling method), kept in 301 aerated tanks and fed fresh Artemia nauplii and blue mussel mantle until molting into J1 crabs. All crabs metamorphosed 1 to $2 \mathrm{~d}$ before the start of the experiment. To ensure that food was not limiting growth during the experiment, frozen Artemia nauplii (first $10 \mathrm{~d}$ only), mysid shrimp and blue mussel mantle were provided daily in surplus. Higher levels of food were provided to tanks with higher densities of crabs, adjusting the levels so that some food always remained uneaten. Excess food and waste products were carefully siphoned out of the tanks daily. This procedure and the high water circulation ensured a high water quality in all treatments through out the duration of the experiment. The experiment was terminated after $30 \mathrm{~d}$ when mussel shells were carefully rinsed and soaked in fresh water for a minimum of $30 \mathrm{~min}$; tank contents, including sediment and habitat rinse water were sieved through a $750 \mu \mathrm{m}$ mesh and all remaining crabs were enumerated and measured live. Surviving crabs were released at the end of the experiment. Losses due to handling are very low (0 to $3 \%$ ) using this recovery technique (Moksnes et al. 1998) and all losses of crabs in the experiments were treated as mortality. Water temperature and salinity varied between 14.5 and $17.9^{\circ} \mathrm{C}$, and 21 and 32 , respectively during the experiment.

$\mathrm{CW}$ at the end of the experiment minus $1.5 \mathrm{~mm}$ (average size of 1st instar crabs; Mohamedeen \& Hartnoll 1989) was used as the growth variable in the analysis, because carapace width of juvenile shore crabs correlates well with ash-free dry weight (KleinBreteler 1975c, Pihl \& Rosenberg 1982). Average growth $(\mathrm{CW}, \mathrm{mm})$ was used as the dependent variable in a 1-factor ANOVA-model with density (10, 40 and 160) as the independent variable. All data were tested for homoscedasticity with Cochran's C-test (Sokal \& Rohlf 1981) and transformed only if found to be hetero- scedastic before the ANOVA was performed. In the analysis of average growth, variance remained heteroscedastic despite transformations and the hypothesis was rejected at $\alpha$ levels lower than the p-value of Cochran's C-test (Underwood 1981). A posteriori multiple comparison tests were carried out with the Student-Newman Keuls (SNK) procedure.

Expt 2 (flume experiment): density-dependent emigration from mussel patches. To assess whether interference competition for space between juvenile crabs could create density-dependent emigration from nursery habitats, a laboratory experiment was performed in 1997 and 1998. The experiment was performed in an annular flume with a mid-channel circumference of $5.3 \mathrm{~m}$ and a width of $0.3 \mathrm{~m}$ (see Hedvall et al. 1998 for details). A slow flow-through current (4 $\left.1 \mathrm{~min}^{-1}\right)$ was created by pumping water from a shallow bay $(750 \mu \mathrm{m}$ filtered) along the annulus. The bottom of the flume was covered with a $2 \mathrm{~cm}$ layer of sieved $(750 \mu \mathrm{m})$ dry beach sand and a constant $40 \mathrm{~cm}$ water depth was maintained (total volume 640 l). Two patches, each consisting of 20 live blue mussels and 10 blue mussel shell halves, were placed at opposite sides of the flume. In 1 patch (randomly chosen), the shell halves consisted of fresh mussels cut in half and were full of meat; the shell halves on the other patch were empty. The 2 patches were separated by approximately $2.4 \mathrm{~m}$ of open sand. Three densities $(2,6$ and $18 \mathrm{crabs})$ of 5 th to 7 th instar juvenile shore crabs (J5-7; 6.5 to $11.5 \mathrm{~mm}$ $\mathrm{CW}$ ) were assessed separately in the flume and replicated over time $(n=7)$. Three replicates at each density were performed in late September and October 1997 , followed by 4 additional replicates at each density treatment in June 1998, using crabs that settled late in the fall the previous year. At the start of an experimental trial, the crabs were individually introduced to the water surface above the patch containing food. Two PVC-partitions were initially placed on each side of the patch to stop emigration of crabs disturbed by the handling. The partitions were carefully removed after 30 min when all crabs had taken shelter. After approximately 24 h, 4 PVC-partitions were pushed down separating each mussel patch (about $66 \mathrm{~cm}$ of the annulus was collected for each patch) and all crabs were collected with hand nets, enumerated and measured. Crabs were scored as either collected on the mussel patch with food, on the patch without food or on the open sand. Crabs that were not collected in the mussel patch with food were considered emigrants. Water temperature and salinity varied between 11.5 and $17.0^{\circ} \mathrm{C}$ and 22 and 31 , respectively during the experimental periods.

Proportional emigration (no. emigrants/total no. of crabs) served as the dependent variable in a 2 -factor ANOVA with Density (2, 6 and 18 crabs) and Season 
(fall and spring trials) as the independent variables. To assess if the molt stage of the crabs affected emigration rates, all recovered crabs in the spring trials were individually placed in cups $(0.5 \mathrm{l})$ and monitored for molt during $48 \mathrm{~h}$ following the termination of each trial.

Expt 3 (field experiment): density-dependent dispersal within nursery areas. To assess if movements of juvenile shore crabs within nursery areas are affected by density-dependent interactions between similarly sized crabs, a field experiment was carried out in August and September 1996. The study was performed in 2 small (1.5 to 2.4 ha), semi-exposed, soft sediment bays, Bökevik and Torseröd, in the Gullmarsfjord (Fig. 1). Both bays have a shallow depth (average $0.5 \mathrm{~m}$ ) that increases rapidly at the bay opening down to 15 to $20 \mathrm{~m}$ and they are surrounded by extensive areas of exposed rocky coast. The topography makes each bay a well defined nursery area with isolated sub-populations of juvenile shore crabs since juvenile migration to and from the bays during the summer is negligible (Moksnes 2002). The bays had a similar mosaic habitat distribution with small $\left(0.1\right.$ to $\left.10 \mathrm{~m}^{2}\right)$ patches of blue mussels and eelgrass covering about 4 to 8 and 13 to $19 \%$ of the bays' shallow $(<1 \mathrm{~m})$ area, respectively (see Moksnes 2002 for further detail of the bays).

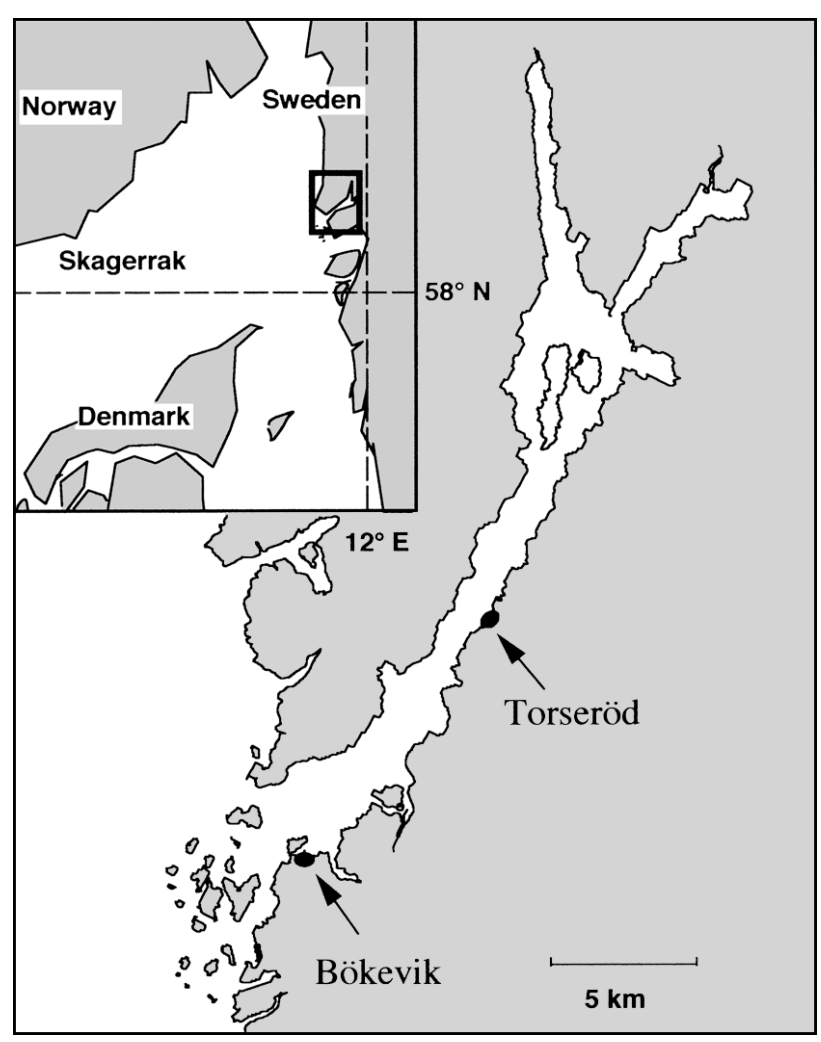

Fig. 1. Location of the Gullmarsfjord (western Sweden) and the 2 bays, Bökevik and Torseröd, where the field experiment and field samplings were carried out
In the experiment, I placed empty patches of blue mussels in the nursery areas and tested for densitydependent relationships between the number of juvenile crabs that colonized the patches over a $3 \mathrm{~d}$ period and the abundance of crabs within nursery areas at different dates, using linear regression analyses. Blue mussels were chosen as a colonizing habitat because juvenile crabs actively select blue mussels (Hedvall et al. 1998, Moksnes 2002). The habitat patches consisted of 50 to 60 live adult blue mussels ( 70 to $80 \mathrm{~mm}$ long) creating a circular patch of approximately $0.14 \mathrm{~m}^{2}$, which were placed at least $20 \mathrm{~m}$ from the nearest natural mussel or eelgrass bed. Separate mussel patches were used for 2 size-classes of colonizing shore crabs that were analyzed as dependent variables: J5-7 crabs (5.0 to $11.5 \mathrm{~mm} \mathrm{CW}$ ), which was the same size-class used in the laboratory migration experiment and J2-3 crabs (1.8 to $3.4 \mathrm{~mm} \mathrm{CW}$ ). Mussel patches used for the smaller size-class were provided with cages with a $2 \mathrm{~mm}$ mesh that allowed J3 and smaller crabs to enter, but stopped potential predators, to avoid confounding colonization estimates with predation mortality. Potential artifacts from these cages affecting settlement densities in shore crabs have been assessed in separate experiments and found to be small (Moksnes 2002). Settling shore crab postlarvae can not metamorphose into J2 crabs in only $3 \mathrm{~d}$ (Mohamedeen \& Hartnoll 1989), so the J2-3 crabs collected in experimental plots had migrated from nearby habitats. Two to 4 patches of the 2 mussel treatments were deployed in each trial and the experimental setup was assessed in 6 trials, 3 times in each of the 2 bays over a 7 wk period. At the start of an experimental trial, mussels and cages were carefully emptied on epifauna. After approximately $72 \mathrm{~h}$, the $0.14 \mathrm{~m}^{2}$ plots with or without cages were collected using suction sampling techniques (cf. Orth \& van Montfrans 1987), and juvenile crabs were enumerated and measured in the laboratory.

The choice of size-classes for the independent variables was based on the assumption that interference competition affecting dispersal rates would only occur between similarly sized crabs, since larger juveniles will cannibalize smaller conspecifics if a critical sizeratio is present (Moksnes et al. 1998). To avoid including sizes of crabs that could have cannibalistic interactions with the colonizing crabs, the density of J4-9 crabs (3.5 to $20 \mathrm{~mm} \mathrm{CW}$ ) and J2-3 crabs in the nursery areas were used as the independent variables for J5-7 and J2-3 crabs, respectively. The average density of crabs in the nursery areas was considered to be a better variable for the analyses than the density of crabs in a specific habitat, because mussel beds and other nursery habitats may become saturated, resulting in proportionally higher densities of juvenile crabs in suboptimal habitats during periods of high densities of crabs. The 
average density of crabs in the nursery areas was estimated by taking six $0.14 \mathrm{~m}^{2}$ random samples from each of the 4 dominant micro-habitat types: blue mussel, eelgrass, filamentous algal patches (when present) and open sand, directly after the experimental trials (forfurther detail concerning sampling techniques see Moksnes 2002). The proportional habitat distribution in the bays at each sample date was estimated by taking 100 to 150 random, $0.25 \mathrm{~m}^{2}$, visual samples of the habitats. By multiplying the distribution of each microhabitat with the juvenile shore crab density in that habitat and adding all habitat densities together, an estimate of the average shore crab density was obtained, which served as the independent variable.

The mean number of colonizing crabs of 2 to 4 replicate habitat plots from each trial was used as dependent variables in the regressions to achieve independence of data. Two dependent variables were analyzed for each size-class: (1) number of colonizing crabs and (2) $\log (x+1)$-transformed number of colonizers. If dispersal rates of crabs were densitydependent and correlated to the encounter probability between crabs, the number of colonizers should increase exponentially with field densities and a logtransformation of the data should increase the fit in the regression. Salinity and temperature varied between 18 and 32 , and 13 and $21^{\circ} \mathrm{C}$, respectively during the experimental period.

\section{RESULTS}

\section{Expt 1: density-dependent growth}

One replicate of crab density 10 was lost. The number of dead crabs recovered was low (0 to $3 \%$ ). A significantly lower growth rate was found at the highest crab density $\left(2.8 \mathrm{~mm} \mathrm{30} \mathrm{d}^{-1}\right)$ compared with the 2 lower crab densities where growth was the same $(3.7 \mathrm{~mm}$ $30 \mathrm{~d}^{-1}$; ANOVA; $F=13.0, \mathrm{df}=2,8, \mathrm{p}<0.01$; SNK test at $\mathrm{p}<0.01$, Fig. 2). Proportional mortality also varied with crab density and was 7,15 and $36 \%$ at crab densities 10, 40 and 160 crabs per tank, resulting in 9, 34 and 103 survivals, on average, from each density, respectively. The frequency distribution of crab sizes showed a large variance in growth rate within each density treatment (2.3 to $7.0 \mathrm{~mm} \mathrm{CW}$; Fig. 2) and was bimodal with few crabs around $5 \mathrm{~mm} \mathrm{CW}$ at all densities. At the 2 lower crab densities, 54 and $49 \%$ of all crabs were found in the larger size group ( $\geq 5 \mathrm{~mm} \mathrm{CW}$ ) with mean sizes of 6.2 and $6.3 \mathrm{~mm} \mathrm{CW}$, respectively. At the highest crab density, only $17 \%$ of all crabs were found in the larger size group, with a mean size of $6.0 \mathrm{~mm} \mathrm{CW}$. A test of the proportion of crabs $\geq 5 \mathrm{~mm}$ CW between crab densities showed that this difference was significant
(ANOVA; $F=7.9, \mathrm{df}=2,8, \mathrm{p}<0.05$ ), suggesting that the reduction in growth at the highest density was due mainly to an increase in the intermolt periods. Growth at low and medium densities corresponds to growth rates obtained with individually raised crabs that were fed in excess at $20^{\circ} \mathrm{C}$ (approximately $4.0 \mathrm{~mm} \mathrm{30} \mathrm{d}^{-1}$; Klein-Breteler 1975b), suggesting that the growing conditions in the mesocosms at the lower densities were close to optimal.

\section{Expt 2 (flume experiment): density-dependent emigration from mussel patches}

All crabs were recovered and no mortality occurred in the experiment. A significantly higher proportion of crabs emigrated from the mussel patch at the highest density (18 crabs; 45\%) compared with the 2 lower densities (21 and 17\% emigration at 2 and 6

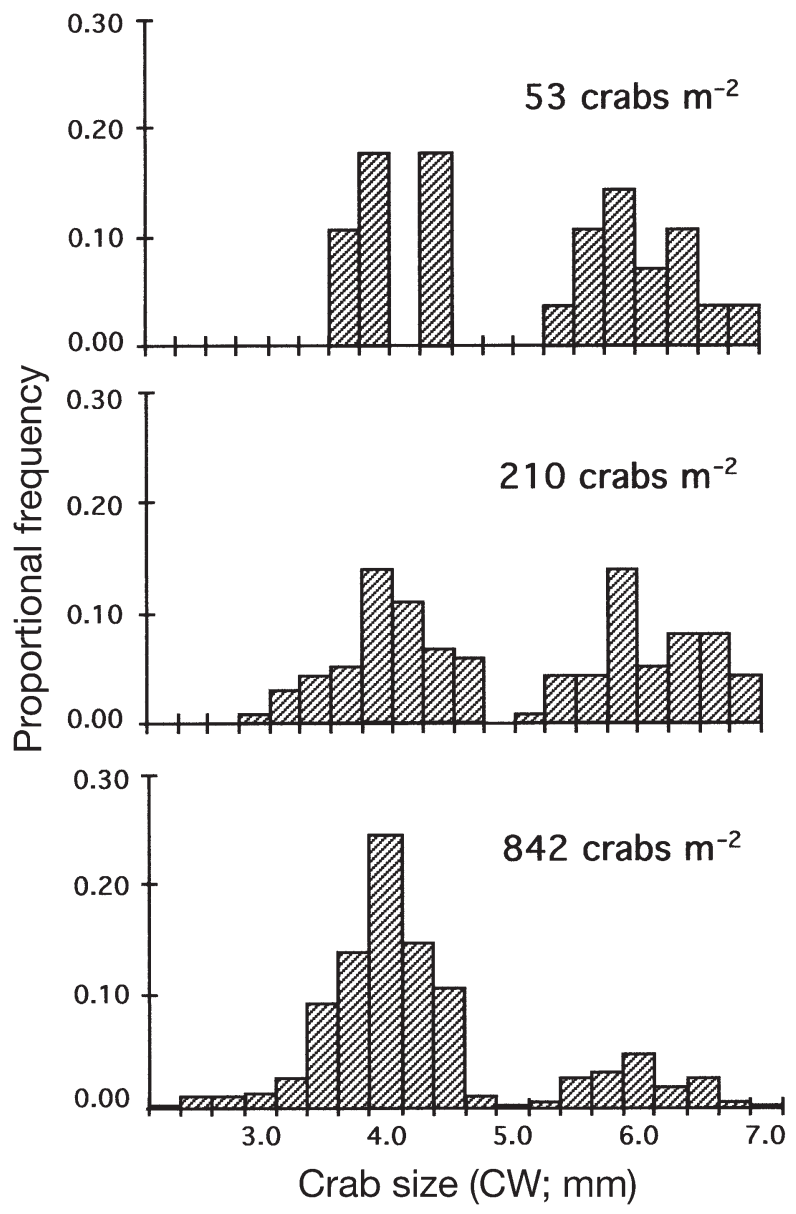

Fig. 2. Carcinus maenas. Density-dependent growth. Proportional size-frequency distribution of 1st instar crabs after $30 \mathrm{~d}$ as a function of initial crab density (equivalent to 53, 210 and $842 \mathrm{crabs} \mathrm{m}^{-2}$ ). Data are pooled from all replicates. CW: carapace width 


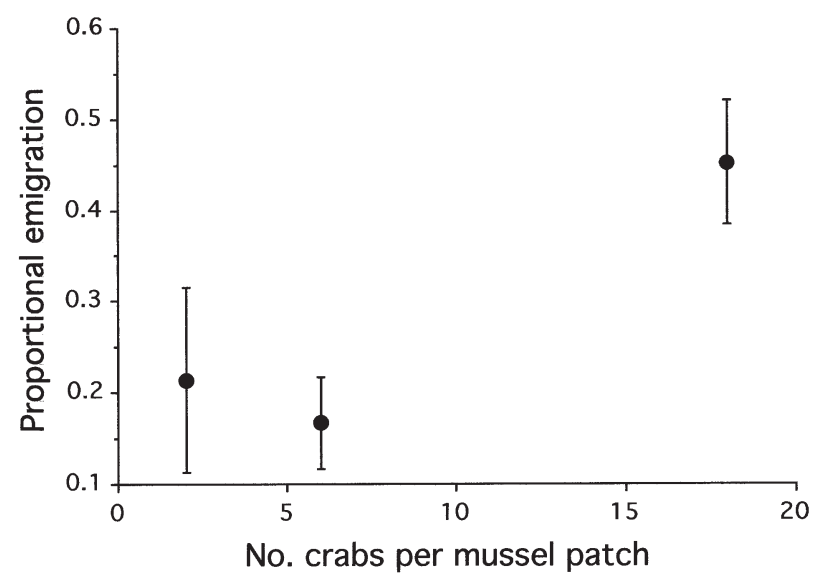

Fig. 3. Carcinus maenas. Flume experiment: density-dependent emigration. Mean proportion of emigrated crabs $24 \mathrm{~h}^{-1}( \pm \mathrm{SE})$ as a function of crab density $(2,6$ and 18 crabs per mussel patch). Data are pooled from the fall and spring trials since no significant difference was found between year classes

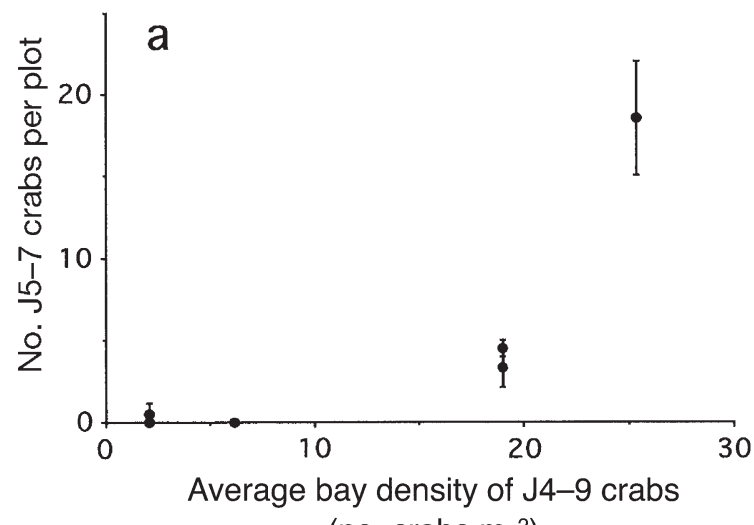

(no. crabs $\mathrm{m}^{-2}$ )

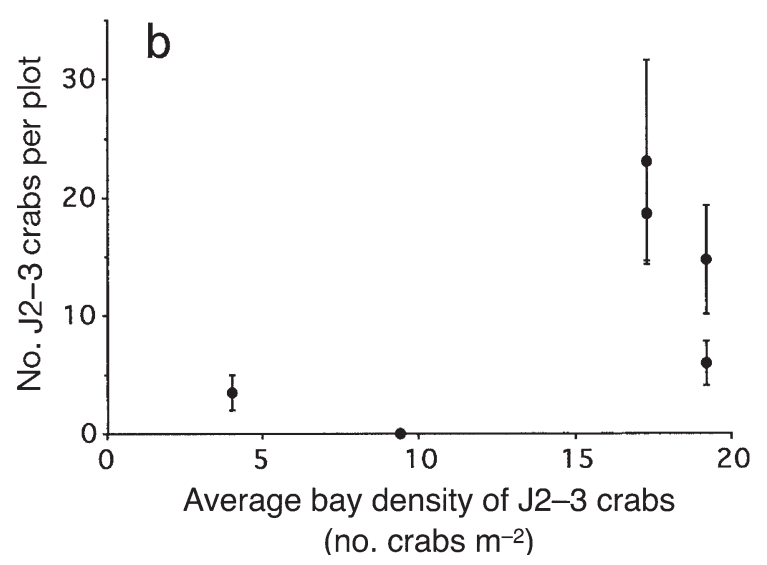

Fig. 4. Carcinus maenas. Field experiment: density-dependent dispersal. (a) Relationship between mean number of J5-7 crabs in experimental mussel patches and average density of J4-9 crabs in nursery areas (independent variable). (b) Relationship between mean number of J2-3 crabs in mussel patches with predator exclusion cages and average density of J2-3 crabs in nursery area
Table 1. Carcinus maenas. Flume experiment: densitydependent emigration. A 2-factor ANOVA model testing proportion of emigrating juvenile shore crabs (6.5 to $11.5 \mathrm{~mm}$ $\mathrm{CW})$ as a function of crab density $(2,6$ and 18 crabs $)$ and season (fall and spring trials). ${ }^{*} \mathrm{p}<0.05$, (ns) $\mathrm{p}>0.05$

\begin{tabular}{|lrcl|}
\hline Source of variation & df & SS & \multicolumn{1}{c|}{$F$} \\
\hline Density (A) & 2 & 0.323 & $3.9^{*}$ \\
Season (B) & 1 & 0.101 & $2.4(\mathrm{~ns})$ \\
A $\times$ B & 2 & 0.011 & $0.1(\mathrm{~ns})$ \\
Residual & 15 & 0.622 & \\
\hline
\end{tabular}

crabs, respectively), which did not differ from each other. No difference was found between experiments in the fall and spring (Table 1; SNK test at $\mathrm{p}<0.05$; Fig. 3). Most of the crabs that emigrated (67\%) were recovered in the other mussel patch. The mean size of crabs used in the 3 treatments was similar (9.0 to $9.4 \mathrm{~mm} \mathrm{CW}$ ) and no difference in crab size was seen between crabs that remained in the food habitat and those recovered in the other mussel patch or on the open sand (9.1, 9.2 and $9.2 \mathrm{~mm} \mathrm{CW}$, respectively). Only a few molts $(5 \%)$ occurred during the experiment and $78 \%$ of all exuviae were recovered in the mussel habitat with food. Molt rates during the $48 \mathrm{~h}$ following the spring trials were low and similar between emigrating and non-emigrating crabs (on average $6 \%$ ) suggesting that the observed emigration was not induced by ecdysis.

\section{Expt 3 (field experiment): density-dependent dispersal within nursery areas}

A large settlement peak occurring in the beginning of August in both bays resulted in high temporal variation in the density of juvenile crabs over the $7 \mathrm{wk}$ experimental period. A high number of juvenile shore crabs colonized the mussel patches during the $3 \mathrm{~d}$ trials, and colonization rates differed between dates and increased exponentially in response to densities of similarly sized crabs in the nursery areas. The number of colonizing J5-7 crabs was below 5 crabs plot $^{-1}$ when the average density of J4-9 crabs in the nursery areas was below $20 \mathrm{crabs} \mathrm{m}^{-2}$, but increased exponentially to $18 \mathrm{crabs}$ plot $^{-1}$ when the average density reached $25 \mathrm{crabs} \mathrm{m}^{-2}$ (Fig. 4a). An exponential increase was supported by the linear regression analyses. The number of J5-7 colonizers did not correlate significantly to the average densities of J4-9 crabs in the bays and showed a poor fit with non-random residuals (Table 2 , Fig. 4), whereas log-transformed data showed a significant correlation and good fit (Table 2), suggesting density-dependent dispersal within the nursery areas. When the density of J4-9 crabs in the nursery areas 
Table 2. Carcinus maenas. Field experiment: density-dependent dispersal. Linear regression analysis testing the number of J4-9 and J2-3 shore crabs colonizing mussel habitat plots as a function of average density of respective juvenile size-classes within nursery areas (see 'Materials and methods' for explanation). ${ }^{* *} \mathrm{p}<0.01$, (ns) $\mathrm{p}>0.05$

\begin{tabular}{|c|c|c|c|c|c|c|c|}
\hline \multirow{2}{*}{$\begin{array}{l}\text { Source of } \\
\text { variation }\end{array}$} & \multirow[t]{2}{*}{ df } & \multicolumn{3}{|c|}{ No. crabs } & \multicolumn{3}{|c|}{$\log ($ no. crabs +1$)$} \\
\hline & & SS & F & $r^{2}$ & SS & F & $\mathrm{r}^{2}$ \\
\hline \multicolumn{8}{|l|}{$\mathrm{J} 4-9$} \\
\hline Regression & 1 & 165.4 & $7.5(\mathrm{~ns})$ & 0.65 & 1.17 & $34.8^{* *}$ & 0.90 \\
\hline Residual & 4 & 88.5 & & & 0.13 & & \\
\hline \multicolumn{8}{|l|}{$\mathrm{J} 2-3$} \\
\hline Regression & 1 & 173.9 & 2.8 (ns) & 0.41 & 0.59 & 3.1 (ns) & 0.44 \\
\hline Residual & 4 & 247.6 & & & 0.76 & & \\
\hline
\end{tabular}

mediated the density-dependent processes. The results suggest that density-dependent growth is less important as a regulating mechanism, but may be the dominant selective force in juvenile migration behavior. Densitydependent emigration from refuge habitats, coupled with habitat specific mortality, appears to regulate densities of larger juveniles in the nursery areas and may be the post-settlement process responsible for a shelter bottleneck observed for juvenile shore crab populations in the study area. was low, 53 to $86 \%$ of all J5-7 crabs were found in mussel habitats, which covered on average $6 \%$ of the bottom area in the bays, whereas only 13 to $37 \%$ of the J5-7 crabs were found in this habitat during high densities of crabs. During the highest colonization rate, densities of J4-9 crabs in experimental mussel plots (equivalent to $202 \mathrm{~m}^{-2}$ ) were higher than the concurrent densities in natural mussel beds (161 $\mathrm{crabs} \mathrm{m}^{-2}$ ). The mean size of colonizing J4-9 crabs varied little between dates (5.4 to $6.7 \mathrm{~mm} \mathrm{CW}$ ) and was similar to the mean size of 4 th to 9 th instars in natural mussel beds at the respective time (5.3 to $5.6 \mathrm{CW})$.

A high number of J2-3 crabs colonized the caged patch, but no clear relationship was found to densities of smaller crabs in the bays. Similar to J5-7 crabs, col-

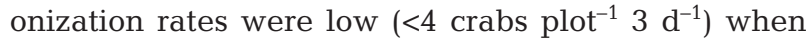
the average density of J2-3 crabs in the nursery areas was below 17 crabs m$^{-2}$, but increased to 23 crabs plot $^{-1}$ $3 \mathrm{~d}^{-1}$ at higher densities. However, the variation was large and neither the number of J2-3 colonizers nor log-transformed data correlated significantly to the average densities of J2-3 crabs in the bays (Fig. 4b, Table 2). During the highest colonization rates, densities of J2-3 crabs in experimental mussel plots (equivalent to $170 \mathrm{~m}^{-2}$ ) were similar to the concurrent densities in natural mussel beds (188 crabs $\left.\mathrm{m}^{-2}\right)$. Peak colonization rates of J2-3 occurred in August whereas colonization rates of J5-7 crabs peaked in late September, suggesting that physical variables in the nursery areas did not have a major impact on the dispersal rates.

\section{DISCUSSION}

This study demonstrates that density-dependent growth and dispersal from nursery habitats can be found in juvenile shore crabs, even when food is in excess, suggesting that interference competition for space

\section{Density-dependent interference and growth}

The growth experiment suggests that feeding rates were negatively affected at higher densities, possibly as a result of both mutual interference and decreased activity of smaller crabs, resulting in densitydependent growth. The growth rate of 1 st instar crabs over a $30 \mathrm{~d}$ period was reduced by $25 \%$ at high densities (equivalent to 842 crabs $\mathrm{m}^{-2}$ ) compared with growth rates at lower densities, due mainly to an increase in the intermolt periods. Growth studies of individually kept juvenile shore crabs have demonstrated a similar effect on growth after a reduction in food (Klein-Breteler 1975b). Since food was provided in excess in all treatments, the present result suggests that space was the limiting resource, and that interference competition reduced feeding rates and growth at higher densities. This suggestion is supported by earlier studies with J5-7 shore crabs that demonstrated $>60 \%$ reduction in feeding rates per crab when crab densities increased from 11 to $32 \mathrm{crabs} \mathrm{m}^{-2}$ (Moksnes 2004). Juvenile shore crabs display a strong defense reaction (raising the front of the body and extending the chelae) when encountering a similarly sized individual (pers. obs.). This aggressive behavior rarely leads to cannibalism, but likely reduces feeding efficiencies at high crab densities. Reduced feeding rates at high conspecific densities have been found in both juvenile (Moksnes et al. 1997) and adult blue crabs Callinectes sapidus Rathbun (Mansour \& Lipcius 1991), and in juvenile Dungeness crabs Cancer magister Dana (Iribarne et al. 1994, Fernández 1999) suggesting that density-dependent interference affecting feeding rates may be common in brachyuran crabs. The present study is the first to provide evidence that mutual interference between crabs may have a direct effect also on growth. Interference competition for space may, therefore, be the mechanism explaining field observations that growth of the first juvenile 
stages in shore crabs decrease later in the season when crab densities are high (Klein-Breteler 1975a).

An alternative explanation for the reduction in mean size at higher crab densities in this study is that the density-dependent mortality, most likely an effect of cannibalism, affected mainly fast growing and large crabs. However, there is little support for this hypothesis since cannibalistic 'reversal' is very unusual (Polis 1981) and has not been observed in shore crabs, and because the observed mortality was not large enough to explain the reduction in size. Simple calculations show that even if cannibalism only affected the largest crabs, the observed mortality (36\%) could only account for $2 / 3$ of the observed reduction in size. Moreover, there was no difference in mean size between the low and intermediate crab density, although proportional cannibalism was twice as high in the latter. Cannibalism tends to reduce variation in size within cohorts by removing smaller, slow growing individuals from the population (Hopper et al. 1996). Such size-specific predation on smaller conspecifics may explain the contrasting results found in growth experiments with juvenile blue crabs, where average crab size increased with crab density and intensity of cannibalism (PerkinsVisser et al. 1996). In the present study, cannibalism may instead have had an indirect effect on growth by affecting the behavior of the smallest crabs, which may become inactive and seek shelter in response to high densities of larger cannibalistic conspecifics, reducing their ability to forage, and further reducing their growth. This suggestion is consistent with laboratory observations of juvenile shore crabs, indicating that smaller individuals eat less and delay molt in the presence of a larger conspecific (Bückmann \& Adelung 1964, Adelung 1971). Such behavioral differences between crabs may explain the unexpectedly large variation in growth within the same treatments $(2.3$ to $7.0 \mathrm{~mm} \mathrm{CW}$ ). This size range includes 2 nd to 6 th instar crabs (Mohamedeen \& Hartnoll 1989) and demonstrates that juvenile crabs can differ up to 5 times in molt frequency during a $30 \mathrm{~d}$ period, even when subjected to the same physical conditions. Because crabs with this variation in growth could easily be mistaken for different cohorts in a field sample (see Fig. 2), the result questions the common practice in field studies of using size distribution of juvenile crabs over time to infer cohorts for estimates of growth and production of populations.

Because predation mortality is substantially higher during the first benthic stages compared with larger juvenile crabs (Moksnes et al. 1998, Moksnes 2002), reduced growth will increase the duration of the predation vulnerable stages and have a direct effect on survival. However, the effect on growth occurred only at unusually high natural densities, which do not prevail for long in nature because of density-dependent inter-cohort cannibalism (Moksnes 2004) and density-dependent dispersal of juvenile crabs (see below). Thus, the importance of density-dependent juvenile growth as a regulating mechanism in shore crabs is probably small in comparison to cannibalism and dispersal.

\section{Density-dependent emigration from nursery habitats}

The demonstrated density-dependent reduction in feeding, growth and survival suggests that fitness of juvenile shore crabs is substantially reduced at naturally high crab densities, which may not balance the refuge value of the nursery habitat, giving emigrating juveniles a selective advantage. This was supported in the laboratory and field experiments, which demonstrated that juvenile crabs emigrate from refuge habitats in response to intra-cohort densities.

In the laboratory flume experiment, J5-7 crabs more than doubled their proportional emigration rate from the mussel habitat when their density increased from 6 to 18 crabs per patch. This density-dependent emigration occurred although food was available in excess, suggesting that space was the limiting factor, consistent with earlier results. Density-dependent dispersal was further supported in the field experiment where an exponential relation was found between colonization rates of empty mussel plots by J5-7 crabs and densities of J4-9 crabs in the nursery areas, which explained $90 \%$ of the variation in colonization rates between dates. Moreover, a shift in habitat use was indicated in which a higher proportion of crabs were found in less preferred seagrass and open sand habitats compared to periods with low densities of shore crabs, suggesting that space in the mussel habitat may have been saturated by J4-9 crabs. In the flume experiment, proportional emigration did not increase when crab densities increased from 2 to 6 crabs per patch, although earlier studies with J5-7 shore crabs, assessing the same densities in similar mussel habitats, demonstrated a $60 \%$ reduction in per capita feeding rates at the higher density (Moksnes 2004). This indicates that emigration rates are not a linear function of encounter probability between crabs or of interference rates, but may involve a trade-off between reduced growth in a crowded refuge habitat and predation outside the habitat, where a substantial reduction in feeding rates are accepted before increased emigration is induced.

High colonization rates of J2-3 crabs were also found in the experimental mussel patches with cages when densities of J2-3 crabs were high in the nursery areas. However, the variation was large and no clear relation was found between colonization rates and crab densi- 
ties in the bays. Variable densities of larger conspecifics may have caused some of this variation. The unexpectedly low colonization rates found at the highest density of J2-3 crabs occurred when there were also high densities of J4-9 crabs in the nursery habitats, which may have decreased the activity of smaller conspecifics. Thus, densities of cannibalistic crabs appear to have negative rather than positive effects on the dispersal rates of J2-3 crabs. Smaller crabs may also be less affected by intra-cohort densities compared to larger juveniles, due to a less developed defense reaction. Observations made during laboratory experiments suggest that the aggressive display in juvenile crabs increases with size and it appears not to be present in J1 crabs. This is supported by similar observations in juvenile Dungeness crabs (Jacoby 1983) and juvenile blue crabs (P.-O. Moksnes unpubl. data). Further studies are necessary to establish if and how intra-cohort densities affect the migration behavior of the smallest crabs. The lack of a clear relation between dispersal rates and crab densities in J2-3 crabs is consistent with laboratory experiments of shore crab megalopae, where settlement densities had only small effects on emigration rates from mussel habitats (Moksnes et al. 2003).

Interference competition for space resulting in density-dependent emigration of juveniles from nursery habitats may be a common behavior in brachyuran crabs and an important regulating mechanism for local recruitment. Consistent with this study, Iribarne et al. (1994) demonstrated, in an elegant series of field experiments, that physical interactions between juvenile Dungeness crabs decreased per capita consumption rates and resulted in density-dependent emigration from shell habitats, which was thought to regulate densities of juveniles in the nursery area. In juvenile blue crabs, feeding rates are also reduced due to density-dependent interference (Moksnes et al. 1997) and density-dependent juvenile emigration has been proposed to regulate juvenile densities in seagrass habitats (Pile et al. 1996, Moksnes et al. 1997, Eggleston et al. 1998). However, recent laboratory and field experiments did not find support for density-dependent dispersal in juvenile blue crabs (Blackmon \& Eggleston 2001, Etherington \& Eggleston 2003), possibly because only moderately high densities were assessed in these studies (16 to $64 \mathrm{crabs}^{-2}$ ), which may have been below a density threshold that induces emigration. In juvenile Dungeness crabs, larger individuals expelled smaller juveniles from shelter and emigrants from nursery habitats were usually smaller crabs (Iribarne et al. 1994). In the present study, I found no support for the hypothesis that migrating shore crabs are smaller subordinates forced to emigrate from preferred habitats by competitive dominants, since emigrants and remaining juveniles were similar in size in both the laboratory and the field experiment. Larger juveniles are less vulnerable to predation compared to smaller crabs (Moksnes et al. 1998), which may reduce the cost of leaving a crowded habitat for larger crabs, balancing the competitive differences.

\section{Space competition and recruitment regulation in shore crabs}

This study demonstrates that interference competition for space and density-dependent emigration from refuge habitats occur at shore crab densities that are regularly found in the study area. These results suggest that nursery habitats become saturated with juveniles during the recruitment season and represent a limiting resource for local populations, and that density-dependent dispersal may constitute an important regulating mechanism for juvenile shore crabs. Although most dispersing crabs remained in the shallow nursery area and the local population (Moksnes 2002), increased movements likely resulted in increased encounter rates with predators and higher mortality. Moreover, because predation mortality is substantially higher on open sand than in refuge habitats for both the earliest instars (Moksnes et al. 1998) and for larger juveniles (Isaksson et al. 1994), density-dependent movements over low refuge habitats should result in density-dependent mortality. Density-dependent juvenile dispersal may also play an important role in stabilizing the dynamics of shore crab populations by mediating mortality from juvenile cannibalism. Cannibalism from larger juveniles on young conspecifics $(<5 \mathrm{~mm} \mathrm{CW})$ is very high and increases both with conspecific prey and cannibal densities, and can regulate new cohorts within days of settlement (Moksnes 2004). If a cannibalistic cohort becomes very abundant, they could eliminate prey cohorts or year classes and cause cyclic fluctuations in the population dynamics (Orr et al. 1990), such as those described for several commercial fish and crab populations (Botsford \& Wickham 1978, Sainte-Marie et al. 1996, Fromentin et al. 1997). Density-dependent dispersal of cannibals from nursery habitats will reduce this risk by decreasing both the number of predators in the settlement habitat and the survival of the cannibals, and subsequently increase the recruitment success of new cohorts. Thus, in shore crabs, juvenile recruitment appears to be regulated by at least 2 strong densitydependent mechanisms acting on different juvenile stages: postlarvae and young juveniles are regulated mainly by density-dependent inter-cohort cannibalism, whereas larger juveniles that have escaped cannibalism through a size refuge and have developed a more aggressive defense display toward conspecifics, are 
regulated through interference competition and density-dependent emigration from refuge habitats. The combination of density-dependent cannibalism and space competition should cause a strong regulation of local recruitment in relation to the abundance of nursery habitats. This suggestion was supported in a largescale field study that compared larval supply and recruitment patterns between local populations and years. This study showed no positive correlation between larval supply and the recruitment of juvenile shore crabs, despite a 10-fold difference in larval abundance between populations and years, but demonstrated a strong and significant correlation between local abundance of nursery habitats and juvenile recruitment (Moksnes 1999). Thus, in this shore crab system, there is evidence of space competition and habitat limitation both from direct studies of the animal's behavior and from field studies at both small and large spatio-temporal scales. These results are consistent with several studies of marine crustaceans suggesting that the availability of juvenile shelter represents a demographic bottleneck for local populations (Steger 1987, Wahle \& Steneck 1991, Beck 1997, Butler \& Herrnkind 1997). The present study suggests that a key post-settlement process responsible for the shelter bottleneck in juvenile shore crab populations is interference competition for space in nursery habitats resulting in density-dependent dispersal of juveniles. These results demonstrate the importance of assessing the behavior of juveniles and the local availability of juvenile habitats to understand and predict population dynamics of shelter-dependent invertebrates and fish.

Acknowledgements. I thank K. L. Heck Jr., A. Hines, R. Lipcius and L. Pihl for critical and helpful comments on early versions of the manuscript. I also thank C. Roberts for providing excellent assistance in the field experiment; O. Hedvall, C. Degerstedt and S. Nilsson for their help with sorting the field samples; J. van Montfrans for generously providing me with 'hogs hair' air-condition filter material; E. Flach for letting me borrow her cages; the staff at Kristineberg Marine Research Station for providing excellent facilities; and L. Pihl for academic and logistic support. This research was made possible through grants from the Swedish Council for Forestry and Agricultural Research (SFAR) and the World Wide Fund For Nature (WWF), 'Kungliga och Hvitfeldska överskottsfonden', 'Hierta-Retzius stipendiefond' from the Royal Swedish Academy of Sciences, 'Birgit och Birger Wåhlströms minnesfond för den Bohuslänska havs-och insjömiljön', and 'Adolf Lindgrens Stiftelse', which are kindly acknowledged.

\section{LITERATURE CITED}

Adelung D (1971) Untersuchungen zur Häutungsphysiologie der Dekapodenkrebse am Beispiel der Strandkrabbe Carcinus maenas. Helgol Wiss Meeresunters 22:66-119

Beck MW (1997) A test of the generality of the effects of shelter bottlenecks in four stone crab populations. Ecology 78 : 2487-2503
Bell JD, Westoby, M (1986) Variation in seagrass height and density over a wide spatial scale: effects on common fish and decapods. J Exp Mar Biol Ecol 104:275-296

Blackmon DC, Eggleston DB (2001) Factors influencing planktonic, post-settlement dispersal of early juvenile blue crabs (Callinectes sapidus Rathbun). J Exp Mar Biol Ecol 257:183-203

Botsford LW, Wickham DE (1978) Behavior of age-specific density-dependent models and the northern California Dungeness crab (Cancer magister) fishery. J Fish Res Board Can 35:833-843

Bückmann D, Adelung D (1964) Der Einfluß der Umweltfaktoren auf das Wachstum und den Häutungsrhythmus der Strandkrabbe Carcinus maenas. Helgol Wiss Meeresunters 10:91-103

Butler MJ IV, Herrnkind WF (1997) A test of recruitment limitation and the potential for artificial enhancement of spiny lobster (Panulirus argus) populations in Florida. Can J Fish Aquat Sci 54:452-463

Caley MJ, Carr MH, Hixon MA, Hughes TP, Jones GP, Menge BA (1996) Recruitment and the local dynamics of open marine populations. Annu Rev Ecol Syst 27:477-500

Eggleston DB, Etherington LL, Ward EE (1998) Organism response to habitat patchiness: species and habitatdependent recruitment of decapod crustaceans. J Exp Mar Biol Ecol 223:111-132

Eriksson S, Edlund A-M (1977) On the ecological energetics of 0-group Carcinus maenas from shallow sandy bottom in Gullmar fjord, Sweden. J Exp Mar Biol Ecol 30: 233-248

Etherington LL, Eggleston DB (2003) Partitioning loss rates of early juvenile blue crabs from seagrass habitats into mortality and emigration components. Bull Mar Sci 72: 371-391

Fernández M (1999) Cannibalism in Dungeness crab Cancer magister: effects of predator-prey size ratio, density, and habitat type. Mar Ecol Prog Ser 182:221-230

Fogarty M, Sissenwine MP, Cohen EC (1991) Recruitment variability and the dynamics of exploited marine populations. Trends Ecol Evol 6:241-246

Fromentin JM, Stenseth NC, Gjøsaeter J, Bjørnstad ON, Falck W, Johannessen T (1997) Spatial patterns of the temporal dynamics of three gadoid species along the Norwegian Skagerrak coast. Mar Ecol Prog Ser 155:209-222

Gosselin LA, Qian PE (1997) Juvenile mortality in benthic marine invertebrates. Mar Ecol Prog Ser 146:265-282

Hedvall O, Moksnes PO, Pihl L (1998) Active habitat selection by megalopae and juvenile shore crabs Carcinus maenas: A laboratory study in an annular flume. Hydrobiologia 375/376:89-100

Hopper KR, Crowley PH, Kielman D (1996) Density dependence, hatching synchrony, and within-cohort cannibalism in young dragonfly larvae. Ecology 77:191-200

Hunt HL, Scheibling RE (1997) Role of early post-settlement mortality in recruitment of benthic marine invertebrates. Mar Ecol Prog Ser 155:269-301

Iribarne OM, Fernández M, Armstrong D (1994) Does space competition regulate density of juvenile Dungeness crab Cancer magister Dana in sheltered habitat? J Exp Mar Biol Ecol 183:259-271

Isaksson I, Pihl L, van Montfrans J (1994) Eutrophicationrelated changes in macrovegetation and foraging of young cod (Gadus morhua L): a mesocosm experiment. J Exp Mar Biol Ecol 177:203-217

Jacoby CA (1983) Ontogeny of behavior in crab instars of the Dungeness crab Cancer magister Dana 1852. Z Tierpsykol 63:1-16 
Klein-Breteler, WCM (1975a) Growth and moulting of juvenile shore crabs, Carcinus maenas, in a natural population. Neth J Sea Res 9:86-99

Klein-Breteler, WCM (1975b) Laboratory experiments on the influence of environmental factors on the frequency of moulting and the increase in size at moulting of juvenile shore crabs, Carcinus maenas. Neth J Sea Res 9:100-120

Klein-Breteler, WCM (1975c) Food consumption, growth and energy metabolism of juvenile shore crabs, Carcinus maenas. Neth J Sea Res 9:255-272

Mansour RA, Lipcius RN (1991) Density-dependent foraging and mutual interference in blue crabs preying upon infaunal clams. Mar Ecol Prog Ser 72:239-246

Mohamedeen H, Hartnoll RG (1989) Larval and post-larval growth of individually reared specimens of the common shore crab Carcinus maenas (L.). J Exp Mar Biol Ecol 134: $1-24$

Moksnes PO (1999) Recruitment regulation in juvenile shore crabs Carcinus maenas: importance of intraspecific interactions in space limited refuge habitats. $\mathrm{PhD}$ thesis, Göteborg University

Moksnes PO (2002) The relative importance of habitat-specific settlement, predation and juvenile dispersal for distribution and abundance of young juvenile shore crabs Carcinus maenas L. J Exp Mar Biol Ecol 271:41-73

Moksnes PO (2004) Self-regulating mechanisms in cannibalistic populations of juvenile shore crabs Carcinus maenas. Ecology 85:1343-1354

Moksnes PO, Wennhage H (2001) Methods for estimating decapod larval supply and settlement: importance of larval behavior and development stage. Mar Ecol Prog Ser 209:257-273

Moksnes PO, Lipcius RN, Pihl L, van Montfrans J (1997) Cannibal-prey dynamics in juveniles and postlarvae of the blue crab. J Exp Mar Biol Ecol 215:157-187

Moksnes PO, Pihl L, van Montfrans J (1998) Predation on postlarvae and juveniles of the shore crab Carcinus maenas: importance of shelter, size and cannibalism. Mar Ecol Prog Ser 166:211-225

Moksnes PO, Hedvall O, Reinvald T (2003) Settlement behavior in shore crab megalopae: Why do postlarvae emigrate from nursery habitats? Mar Ecol Prog Ser 250:215-230

Ólafsson EB, Peterson CH, Ambrose WGJ (1994) Does recruitment limitation structure populations and communities of macro-invertebrates in marine soft sediments: the relative significance of pre- and post-settlement processes. Oceanogr Mar Biol Annu Rev 32:65-109

Orr BK, Murdoch WW, Bence JR (1990) Population regulation, convergence, and cannibalism in Notonecta (Hemiptera). Ecology 71:68-82

Editorial responsibility: Otto Kinne (Editor),

Oldendorf/Luhe, Germany
Orth RJ, van Montfrans J (1987) Utilization of a seagrass meadow and tidal marsh creek by blue crabs Callinectes sapidus. I. Seasonal and annual variation in abundance with emphasis on post-settlement juveniles. Mar Ecol Prog Ser 41:283-294

Palmer MA, Allan JD, Butman CA (1996) Dispersal as a regional process affecting the local dynamics of marine and stream benthic invertebrates. Trends Ecol Evol 11: 322-326

Perkins-Visser E, Wolcott TG, Wolcott DL (1996) Nursery role of seagrass beds: Enhanced growth of juvenile blue crabs (Callinectes sapidus Rathbun). J Exp Mar Biol Ecol 198: 155-173

Pihl L (1986) Exposure, vegetation and sediment as primary factors for mobile epibenthic faunal community structure and production in shallow marine soft bottom areas. Neth J Sea Res 20:75-84

Pihl L, Rosenberg R (1982) Production, abundance, and biomass of mobile epibenthic marine fauna in shallow waters, western Sweden. J Exp Mar Biol Ecol 57:273-301

Pile AJ, Lipcius RN, van Montfrans J, Orth RJ (1996) Density dependent settler: recruit: juvenile relationships in blue crabs: mechanisms and effects of a tropical storm. Ecol Monogr 66:277-300

Polis GA (1981) The evolution and dynamics of intraspecific predation. Annu Rev Ecol Syst 12:225-251

Sainte-Marie B, Sénigny JM, Smith BD, Lovrich GA (1996) Recruitment variability in snow crab (Chionoecetes opilio): pattern, possible causes, and implications for fishery management. In: Baxter B (ed) High latitude crabs: biology, management, and economics. Proceedings of the international symposium on biology, management and economics of crabs from high latitude habitats. Lowell Wakefield Fish Symp Ser, Alaska Sea Grant Report No. 96-02, p 451-478

Sokal RR, Rohlf FJ (1981) Biometry: the principles and practice of statistics in biological research. WH Freeman, New York

Steger R (1987) Effects of refuges and recruitment on gonodactylid stomatopods, a guild of mobile prey. Ecology 68: 1520-1533

Underwood AJ (1981) Techniques of analysis of variance in experimental marine biology and ecology. Oceanogr Mar Biol Annu Rev 19:513-605

Wahle RA, Steneck RS (1991) Recruitment habitats and nursery grounds of the American lobster, Homarus americanus: a demographic bottleneck? Mar Ecol Prog Ser 69: 231-243

Yamada SB (2001) Global invader: the European green crab. Oregon Sea Grant, Oregon State University, Corvallis, OR

Submitted: February 25, 2004; Accepted: June 22, 2004

Proofs received from author(s): October 12, 2004 